\title{
Grammatical change in the noun phrase: the influence of written language use
}

\author{
DOUGLAS BIBER and BETHANY GRAY \\ Northern Arizona State University
}

(Received 10 May 2010; revised 7 January 2011)

\begin{abstract}
Many discussions of grammatical change have focused on grammatical innovation in the discourse contexts of conversational interaction. We argue here that it is also possible for grammatical innovation to emerge out of the communicative demands of written discourse. In particular, the distinctive communicative characteristics of academic writing (informational prose) have led to the development of a discourse style that relies heavily on nominal structures, with extensive phrasal modification and a relative absence of verbs. By tracking the historical development of this discourse style, we can also observe the development of particular grammatical functions that are emerging in writing. We focus here on two grammatical features - nouns as nominal premodifiers and prepositional phrases as nominal postmodifiers - analyzing their historical development over the last four centuries in a corpus of academic research writing (compared to other registers such as fiction, newspaper reportage and conversation). Our analysis shows that these grammatical features were quite restricted in function and variability in earlier historical periods of English. However, in the nineteenth and twentieth centuries, they became much more frequent and productive, accompanied by major extensions in their functions, variants, and range of lexical associations. These extensions were restricted primarily to informational written discourse, illustrating ways in which new grammatical functions emerge in writing rather than speech.
\end{abstract}

\section{Introduction}

Over the past two decades, there has been considerable interest in how grammatical change is realized in actual language use, carried out in relation to the study of 'grammaticalization', 'usage-based approaches', 'emergent grammar' and the general study of 'frequency effects' in language use. These approaches share a focus on discourse, describing how new grammatical constructions and/or functions emerge from natural communicative situations.

A few of these studies have been careful to acknowledge the possibility of historical change in writing as well as speech. For example, Traugott (2003: 125) defines 'subjectification' as the tendency of meanings 'to become increasingly based in the $\mathrm{SP}$ [eaker]/W[riter]'s subjective belief state or attitude to what is being said and how it is being said'.

More often, though, discourse-based studies of grammatical change focus at least implicitly on spoken interaction, using the term 'speaker' as a cover term for the addressor or producer of discourse, and often framing the discussion in terms of 'utterances' and conversational 'interaction'. Written discourse has generally received 
little attention, with most studies simply disregarding the possibility that grammatical innovations could develop in natural written communication.

For example, an exclusive focus on spoken interaction is front-and-center in the edited book on Interaction and Grammar by Ochs, Schegloff \& Thompson (1996), which approaches grammar as part of the social practices associated with conversational interaction. These studies thus analyze transcripts of conversations, showing how grammar emerges with special functions in interactional contexts. However, a similar implicit emphasis on spoken interaction can be observed in so-called 'usage-based' models (see e.g. Langacker 1987; Kemmer \& Barlow 2000). While these descriptions tend to be based on intuitive notions of spoken interaction, rather than direct analysis of conversational transcripts, they still implicitly frame the discussion relative to speech; for example, the 'usage events' that form the foundation of the usage-based model are 'utterances' produced by 'speakers' (Langacker 2000: 9).

Similarly, in describing the motivations and enabling factors of grammaticalization, Hopper \& Traugott (2003: 71) note that previous research has focused on 'the role of speakers and hearers negotiating meaning in communicative situations'. Bybee $\&$ Hopper (2001) are also typical in their focus on spoken interaction, noting that:

The notion of emergence ... relativizes structure to speakers' actual experience with language, and sees structure as an on-going response to the pressure of discourse ... The distribution and frequency of the units of language are governed by the content of people's interactions ... Patterns of use ... deal with patterns of occurrence of morphosyntactic structures in natural conversation. (3)

Croft (2000) is especially emphatic in arguing that language change occurs in utterances produced by speakers in conversational interaction; for example:

language use is essentially a joint act between speaker and addressee ... Language is a fundamentally social interactional phenomenon. So is language change. (87)

Given this background, it is probably not surprising that many studies of grammaticalization have focused on grammatical features that are common in conversation but rarely used in writing, such as the English semi-modals (e.g. have to, got to; see Krug 2000; Tagliamonte 2004) or discourse markers (e.g. well).

As noted above, most scholars simply disregard the possibility that grammar might also emerge in written use. One of the few exceptions to this trend is Croft (2000), who directly considers the possibility but then strongly argues against it:

One might speculate that the advent of the written medium led to directed evolution in the development of these construction types [e.g. nominalizations, participles, attributive adjectives] ... Typological research indicates, however, that all of these construction types are present in most if not all unwritten languages. (83)

It is thus possible that there is directed change in the advent of the written register. However, expansion into the new linguistic niche results in the evolution at most of new degrees of syntactic complexity - multiple iterations and embeddings of structures rather than in developing completely new grammatical structures. (83-4) 
Croft is specifically focusing on grammatical innovation from a typological perspective: can a new type of grammatical construction emerge in a written language in comparison to the types of constructions that already exist in the world's spoken languages? Our research is not directly relevant to this question: we have not uncovered any evidence concerning the development of newly emerging construction types.

However, we believe that we have uncovered evidence that grammatical innovations in written discourse can go well beyond increased 'iterations and embeddings'. In particular, focusing on noun phrase constructions in English, we document extensions in the range of grammatical variants, the range of lexical associations, and the range of grammatical/semantic functions. These functional extensions have emerged out of the communicative demands of written discourse rather than spoken interaction.

In more general terms, we argue that the communicative demands of any register whether spoken or written - have the potential to facilitate the emergence of grammatical uses (and possibly new constructions) associated with those communicative needs. Fox (2007: 299) is one of the few researchers who has explicitly raised this possibility in the past: 'The relationship of written language to language-ininteraction is complex and worthy of independent study.' In particular, Fox notes that written discourse is produced under completely different circumstances from spoken discourse, and that these characteristics might have direct grammatical consequences:

\footnotetext{
Writers and readers typically have no time constraints placed on their production and comprehension, a fact which presumably allows more complex syntactic structures to arise ... On the other hand, speakers and recipients in real-time conversation have immense time pressures on them [creating] a tendency in conversation towards shorter and syntactically simpler utterances. (314)
}

It is clear ... that writing alone, at leisure ... is a different grammatical enterprise than is designing an utterance, in real time ... the grammar of written language thus needs to be taken up as a separate investigation. (315)

The present study addresses this possibility by investigating grammatical change that has been restricted primarily to written discourse. In particular, we focus here on academic research writing, as a register that differs in almost every way from face-to-face conversation:

- written rather than spoken

- monologic rather than interactive and co-constructed

- requires specialized, professional background knowledge, but no assumption of personal background knowledge

- slowly produced and carefully revised and edited.

If grammatical change is influenced by the pressures of the communicative situation, there is every reason to expect that the grammatical uses emerging in written academic writing will be strikingly different from those that have emerged from conversational interactions. 
As background to our research, we first document the dramatic changes in grammatical discourse style that have occurred over the past two centuries in academic research writing (section 3). In particular, academic writing (and other kinds of informational writing) has developed a grammatical style that relies heavily on phrasal modification. Two characteristics of this style are especially noteworthy: a reliance on nouns (and the relative absence of verbs), and a reliance on phrasal modification (and the relative absence of clausal modification). Thus, in comparison to spoken registers, there are relatively few verbs and clauses in modern academic writing. Instead, this style relies on non-clausal phrases as modifiers. Further, those non-clausal phrases are most commonly embedded in noun phrases rather than functioning as clause elements. Thus, in contrast to conversation as well as popular written registers (like fiction), academic writing is characterized by an extremely dense use of non-clausal phrases and extremely complex noun phrase structures, while there is comparatively little structural elaboration that involves embedded dependent clauses as clause constituents. Section 3 traces the evolution of these characteristics of modern academic research writing, showing how they are relatively recent historical developments that have occurred over the past 150 years.

In section 4, then, we explore some of the new grammatical uses that have emerged in association with this shift in discourse style. Two case studies are briefly presented, each focusing on a particular grammatical device used for noun phrase modification: nouns as nominal premodifiers and prepositional phrases as nominal postmodifiers. These construction types were attested in earlier historical periods of English, but they were relatively restricted in function and variability. Then, in the nineteenth and twentieth centuries, these structures became much more frequent and productive, accompanied by major extensions in their functions, variants and range of lexical associations. As the following sections show, those extensions were restricted primarily to informational written discourse, providing clear examples of new grammatical variants and functions emerging in writing rather than speech.

\section{Methods}

The patterns of use presented in sections 3 and 4 below are based on analysis of several synchronic and historical corpora, representing written academic prose (primarily science/medical research articles), other written registers (newspaper reportage and novels) and spoken language (historical dialogues, present-day face-toface conversation). Table 1 describes the corpora in general terms, and full references to the corpora appear at the end of the article.

The corpora were grammatically annotated ('tagged') using software developed for the Longman Grammar of Spoken and Written English (Biber et al. 1999). Then, more specialized computer programs were developed for detailed linguistic analyses of specific types of noun modification. Automatic rates of occurrence could be calculated for the overall frequency of nouns, relative clauses, attributive adjectives, and nouns as nominal premodifiers based on the 'tagged' texts. However, prepositional phrases and 
Table 1. Corpora used in the analysis

\begin{tabular}{lll}
\hline \hline & Time period & Words \\
\hline $\begin{array}{l}\text { Primary corpus for the analysis } \\
\text { Academic research articles }\end{array}$ & & \\
$\quad$ Early Modern English Medical Texts & $1500-1700$ & c. 500,000 \\
$\quad \begin{array}{l}\text { ARCHER (science, medicine) } \\
\text { Corpus of English Texts on }\end{array}$ & $1700-1990$ & c. 160,000 \\
$\quad$ Astronomy (CETA) & $1700-1900$ & c. 400,000 \\
$\begin{array}{l}\text { 20th Century Research Articles } \\
\text { Comparison corpora }\end{array}$ & $1965,1985,2005$ & c. 655,000 \\
$\begin{array}{l}\text { Newspaper reportage } \\
\text { ARCHER, NY Times }\end{array}$ & & \\
$\begin{array}{l}\text { Fictional novels } \\
\text { Corpus of Historical Fiction }\end{array}$ & $1700-1990$ & c. 250,000 \\
$\begin{array}{l}\text { Drama } \\
\text { ARCHER }\end{array}$ & $1700-1990$ & c. 1.2 million \\
Conversation & $1700-1990$ & c. 75,000 \\
$\quad$ Longman LSWE Corpus & $1990 \mathrm{~s}$ & c. 5 million \\
\hline \hline
\end{tabular}

appositive noun phrases required manual coding to arrive at accurate estimates of their use. Thus, for these two features, a subsample of the corpora was used.

For prepositional phrases as nominal postmodifiers, we coded every fourth occurrence of the prepositions in, on, with and for that was not preceded by a word tagged as a verb. Each occurrence was manually coded to differentiate between prepositional phrases functioning as noun postmodifiers versus all other functions (e.g. adverbials). Normed counts were then computed by multiplying by 4 and then dividing by the total number of words.

For nominal apposition, a program identified all occurrences of the two patterns listed below:

$\begin{array}{ll}\mathrm{NP}+\mathrm{COMMA}+\mathrm{NP} & \begin{array}{l}\text { e.g. James Klein, president of the American Benefits Council } \\ \text { NP + PARENTHESIS + NP. the other member of each twin pair (twin B sample); } \\ \text { Protein expression was assessed by Western blot (anti-myo2p } \\ \text { tail antiserum) }\end{array}\end{array}$

Each automatically identified sequence was then manually coded to identify the ones that were actually occurrences of marked noun apposition.

3 Background: the historical shift to phrasal grammatical styles in informational writing

Several corpus studies over the past two decades have explored the distinctive grammar of written discourse. For example, early Multi-Dimensional (MD) studies of register variation (e.g. Biber 1988) have shown that the discourse style of written informational registers is fundamentally different from spoken registers. 'Dimension 1' from the 


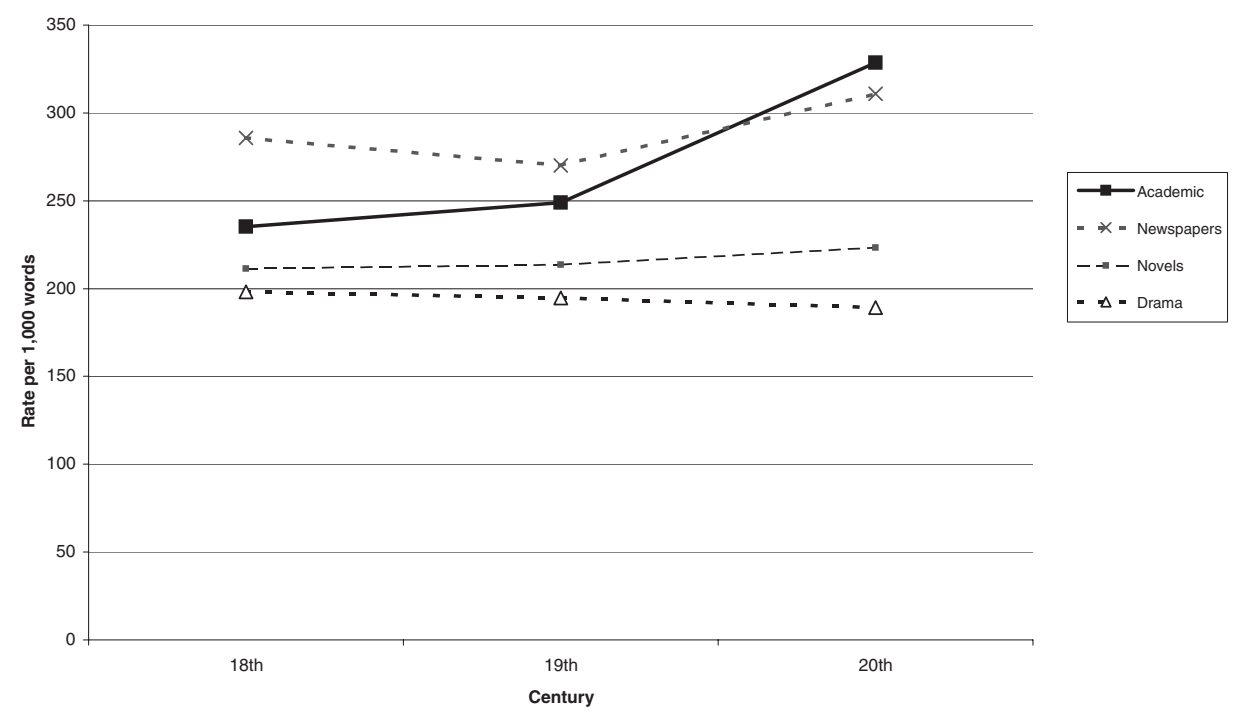

Figure 1. Historical use of nouns

1988 study shows that written informational registers rely heavily on nouns, attributive adjectives, and prepositional phrases, while spoken registers employ extensive clausal embedding (with finite adverbial clauses and complement clauses) together with a dense use of pronouns, stance features, and reduced structures. Biber \& Finegan (1997) use this same MD analysis to document the patterns of historical register change over the past three centuries, showing how academic writing has steadily evolved towards an increasing use of these nominal structures.

The grammatical underpinnings of the development of the nominal style are studied in more detail in Biber \& Clark (2002), based on historical analysis of three registers from the ARCHER Corpus (drama, fiction, academic medical prose). One simple manifestation of the change to a nominal style has been the overall prevalence of nouns in written registers. As figure 1 shows, nouns have increased in use in academic research writing and in newspaper prose over the past three centuries, while their use has remained relatively constant in drama and fiction. Surprisingly, despite this large increase in the use of nouns, there has not been an increase in the clausal elaboration of noun phrases. Thus figure 2 shows that relative clauses have remained relatively infrequent across time, and have actually declined slightly in the three written registers.

In contrast, there has been a dramatic increase in the phrasal elaboration of noun phrases, and that historical change has been restricted primarily to informational writing. As a result, modern academic writing is better described as 'compressed' rather than 'elaborated', characterized generally by the absence of verbs and clauses, and the high density of phrasal modifiers (see e.g. Biber \& Clark 2002; Mair 2006; Biber 2009; Biber \& Conrad 2009; Leech et al. 2009; Biber \& Gray 2010). 


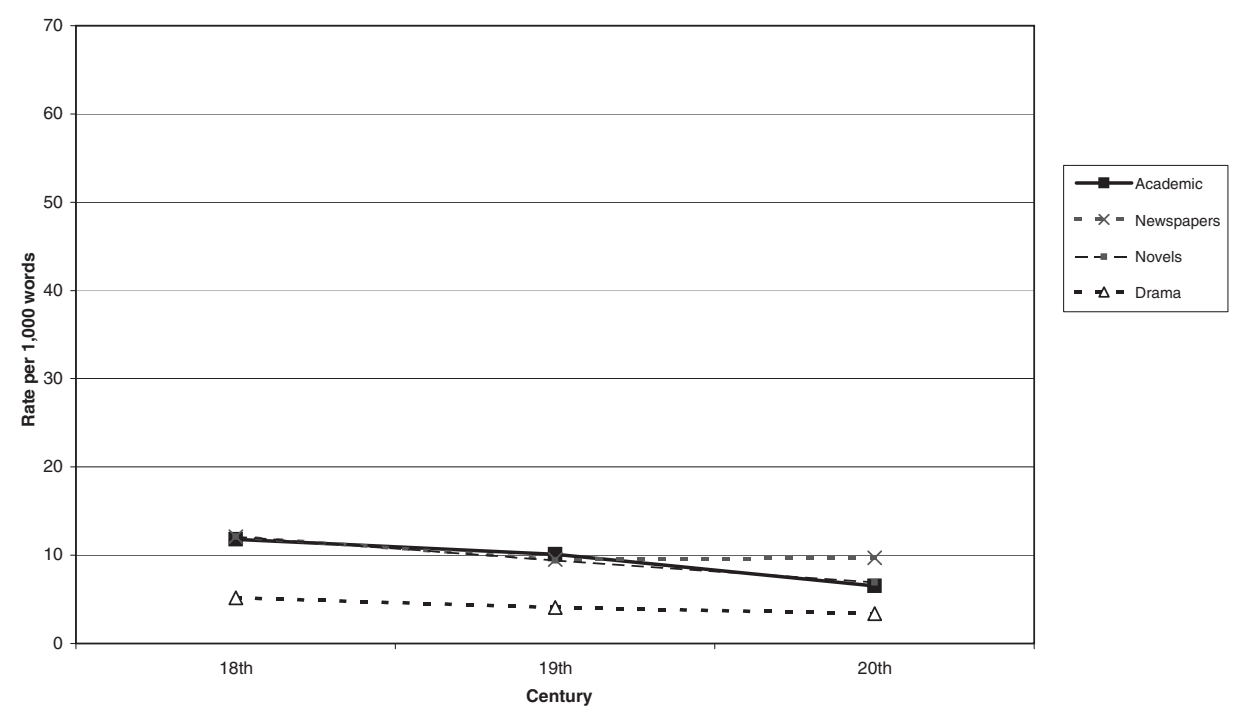

Figure 2. Historical use of relative clauses

Five grammatical devices have been especially important in the development of this 'compressed' discourse style:

- nominalizations (consumption, comparison, sustenance)

- attributive adjectives (gradually expanding cumulative effect)

- nouns as nominal premodifiers (baggage inspection procedures)

- prepositional phrases as nominal postmodifiers (a high incidence of heavy alcohol consumption amongst patients)

- appositive noun phrases (Dallas Salisbury, CEO of the Employee Benefit Research Institute)

Nominalization has been the most studied of these five. Thus, researchers like Halliday (1979), Halliday \& Martin (1993/1996) and Banks (2008) describe the increasing use of nominalizations as the most distinctive characteristic of modern science prose. These studies focus generally on the transformation of dynamic processes expressed as verbs to nouns with static meanings, whether through the use of derivational suffixes (e.g.-tion, -ent, -ance) or through the conversion of verbs to nouns (as in strong increase or flow line). As figure 3 shows, the increased use of nominalizations is an important characteristic of informational written discourse. Thus, nominalizations have increased strongly in both academic prose and newspaper writing, while they have actually decreased in use in novels and drama. Attributive adjectives follow a similar historical pattern, although the changes have been less noteworthy. Thus, figure 4 shows that the use of attributive adjectives has steadily increased in academic prose over the past three centuries, while their use has remained relatively constant in newspaper prose and decreased slightly in drama and fiction. 


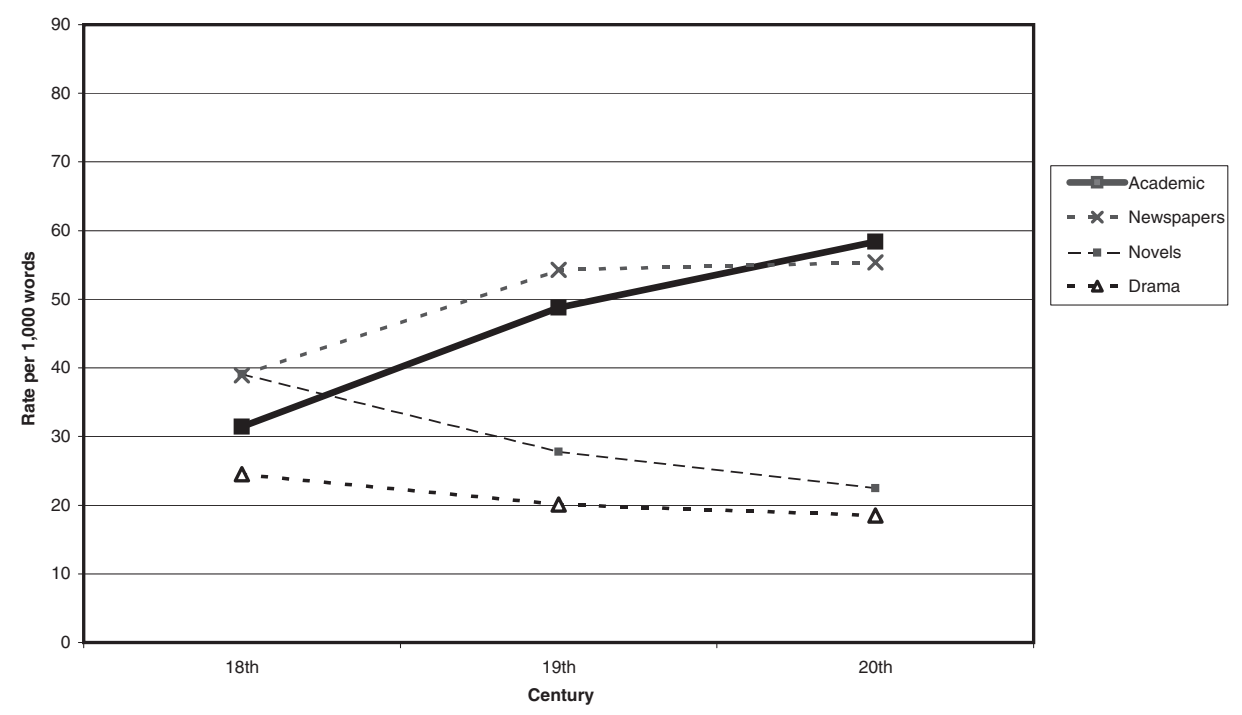

Figure 3. Historical use of nominalizations

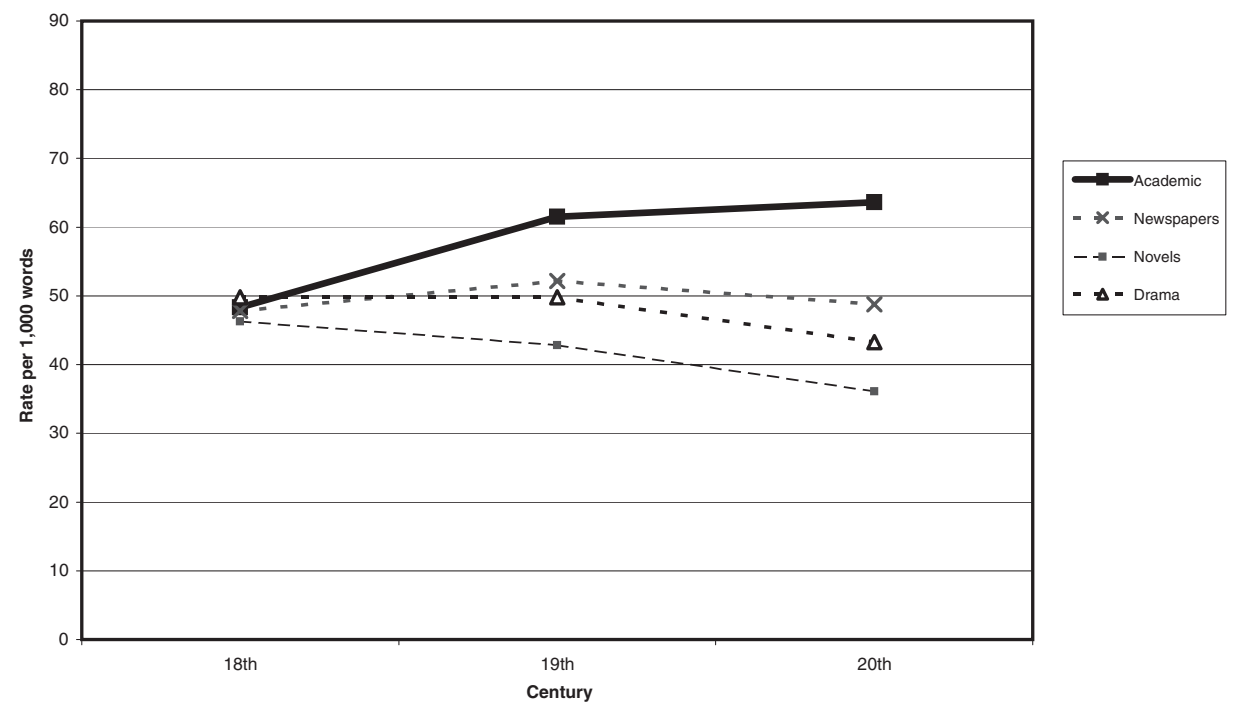

Figure 4. Historical use of attributive adjectives

Historical change in the use of nouns as nominal premodifiers (shown in figure 5) is more dramatic: the use of these modifiers is generally rare up until the twentieth century. However, at that point there was a large increase in both academic prose and newspaper writing, and a smaller increase in fiction writing. In contrast, the use of this device in drama remains rare up to the present day. As figure 6 shows, this increase has been especially pronounced in science research articles (compared to academic writing 


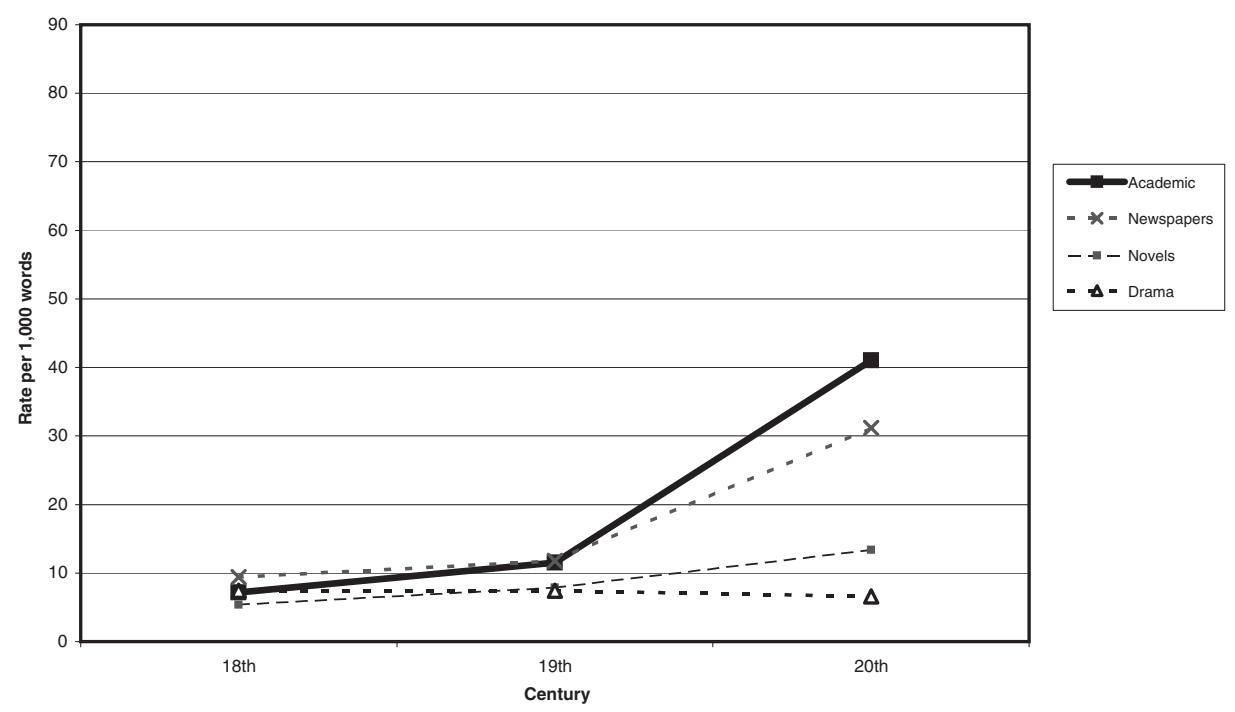

Figure 5. Historical use of nouns as nominal premodifiers

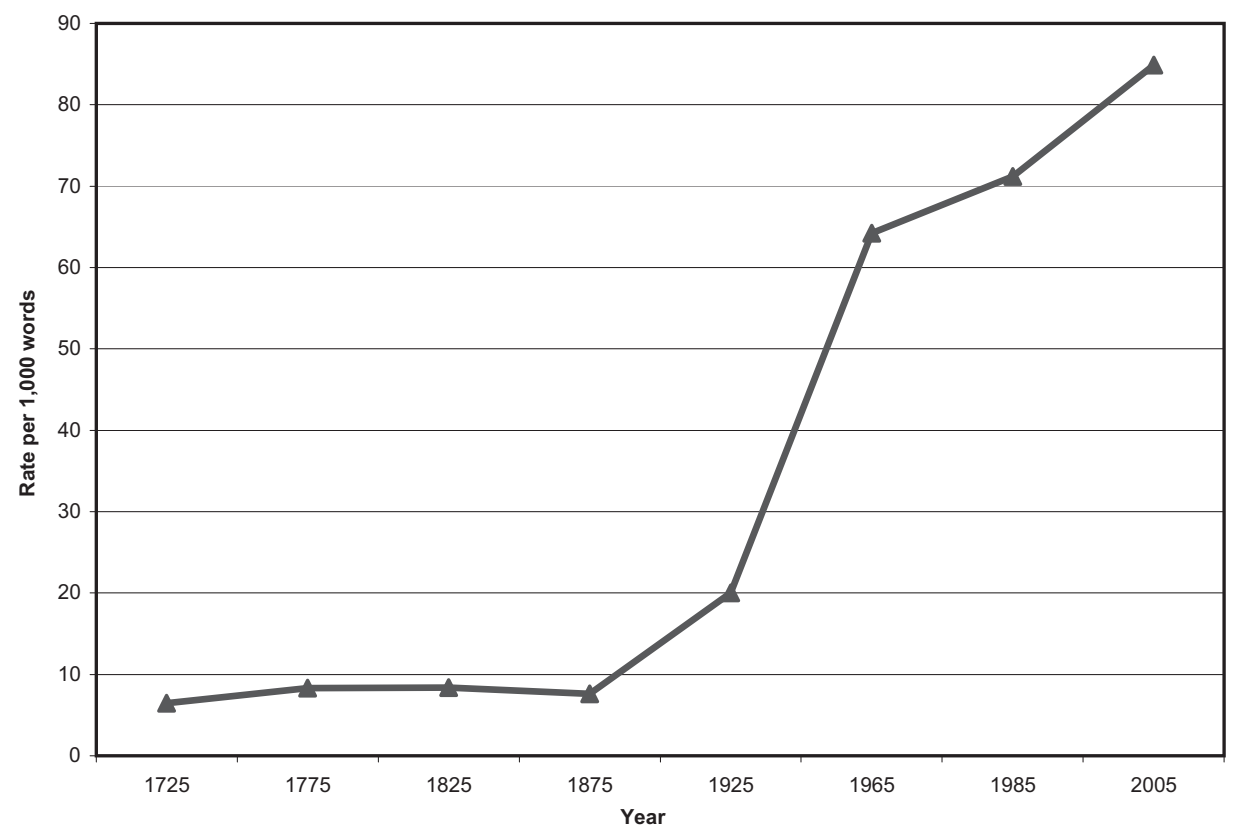

Figure 6. Historical use of nouns as nominal premodifiers, in science research articles 


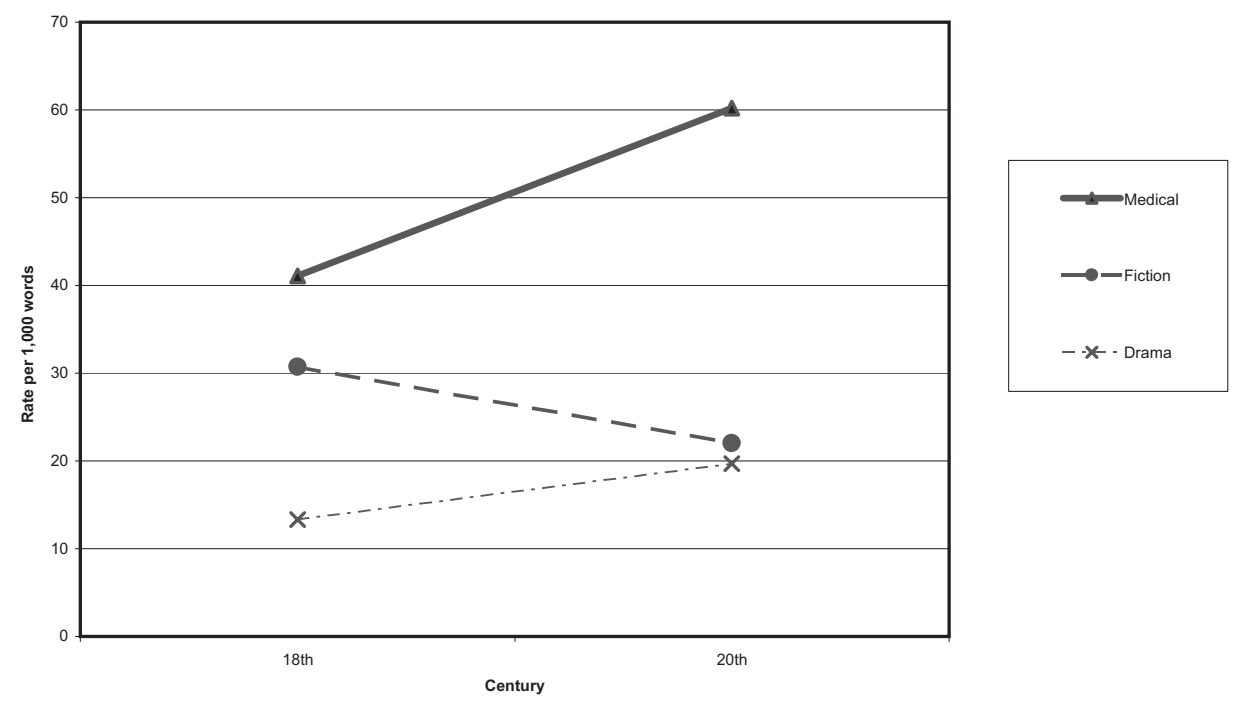

Figure 7. Prepositional phrases as nominal postmodifiers (from Biber \& Clark 2002)

generally). The historical shift begins at the turn of the twentieth century, and then rapidly takes off over the period 1925-65. Nouns as nominal premodifiers continue to increase in use up to the present time, although there is some indication that this development is leveling off in recent decades.

Prepositional phrases are the most common type of postnominal phrasal modifier. Figure 7 plots the historical change in the use of prepositional phrase (PP) noun modifiers. A comparison of figures 7 and 2 shows that PP noun modifiers are about fifteen times more frequent than relative clauses in present-day academic prose. Further, PP noun modifiers have shown a large increase in use over the past two centuries, while the use of relative clauses has remained constant. However, this increase has been restricted primarily to informational writing, while fiction writing actually shows a decrease in the use of PP noun modifiers.

Figure 8 displays the historical change in the use of prepositional phrases as postnominal modifiers, distinguishing between of-genitives and all other prepositional phrases as postnominal modifiers. $O f$-genitives were already frequent in academic writing by the eighteenth century, but their use remained constant over the following centuries. In contrast, other prepositional phrases were not common in the eighteenth century, and that pattern of use continued into the nineteenth century. Similar to the pattern for nouns as premodifiers, the twentieth century witnessed a dramatic increase in the use of PPs as postmodifiers, restricted mostly to informational written discourse. As a result, sentences like (1) are common in present-day academic prose:

(1) Specifically, we were interested in the qualitative ecological difference in emphasis between changes in composition vs. changes in relative abundance. 


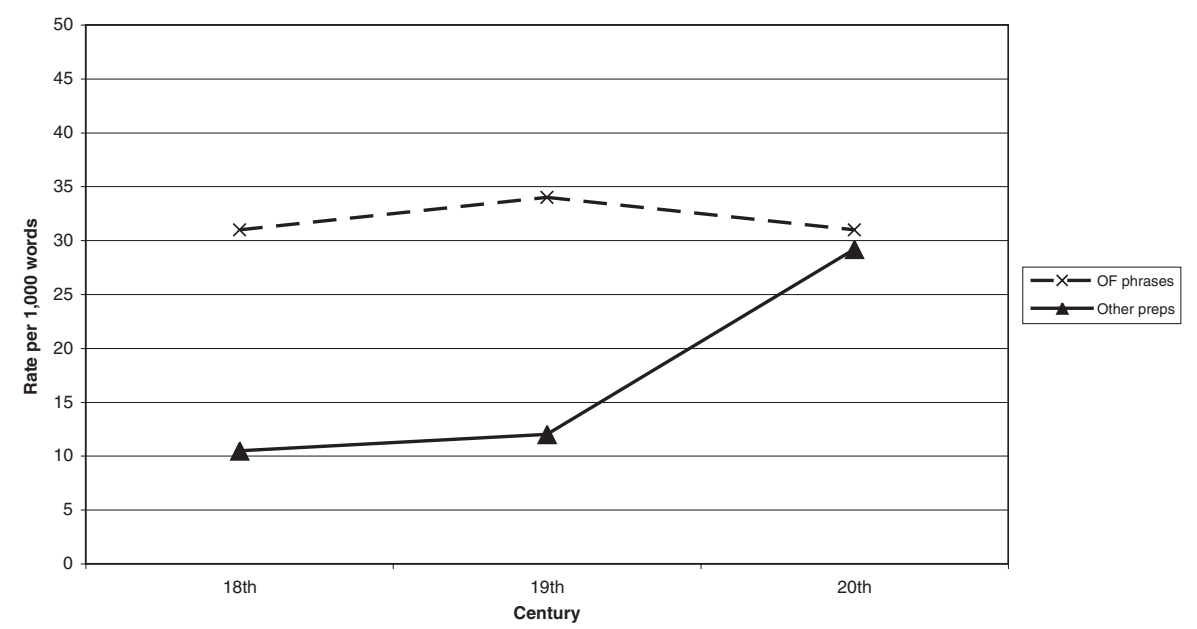

Figure 8. Prepositional phrases as nominal postmodifiers in medical research articles: OF-phrases versus other prepositions (from Biber \& Clark 2002)

Finally, figure 9 shows that the use of appositive noun phrases (also referred to as 'nominal apposition'; Meyer 1992: 10) has changed in a similar way. Although these structures date back to Middle English (see Nevalinna \& Pahta 1997; Pahta \& Nevalinna 1997), they were still relatively rare in the eighteenth and nineteenth centuries. However, appositive noun phrases have become considerably more common in the twentieth century. ${ }^{1}$ Similar to the other types of phrasal noun modifiers, this development has been restricted primarily to informational written registers.

Further, a structural/textual innovation was introduced in the nineteenth century: the use of parentheses to mark the appositive noun phrase, rather than separating the two noun phrases by commas, as in (2) and (3):

(2) In about two months after it had acquired this additional head, a fragment separated from the tail (the most usual place of separation) and was in progress towards its entire reproduction when it was accidently lost ...

(3) the former is composed of sporules, empty tubes (the mycelium), and tubes filled with sporules

As figure 9 shows, this textual device is restricted almost entirely to academic research writing. (The use of appositive noun phrases has also increased in newspaper writing, but that register continues to rely almost entirely on the traditional NP, NP convention.) By using the parentheses convention, it has become common in academic research writing to embed multiple levels of appositive noun phrases, representing complex meaning relationships to the head noun, as illustrated by (4):

\footnotetext{
1 Note that the scale on figure 9 is considerably smaller than figures $2-8$.
} 


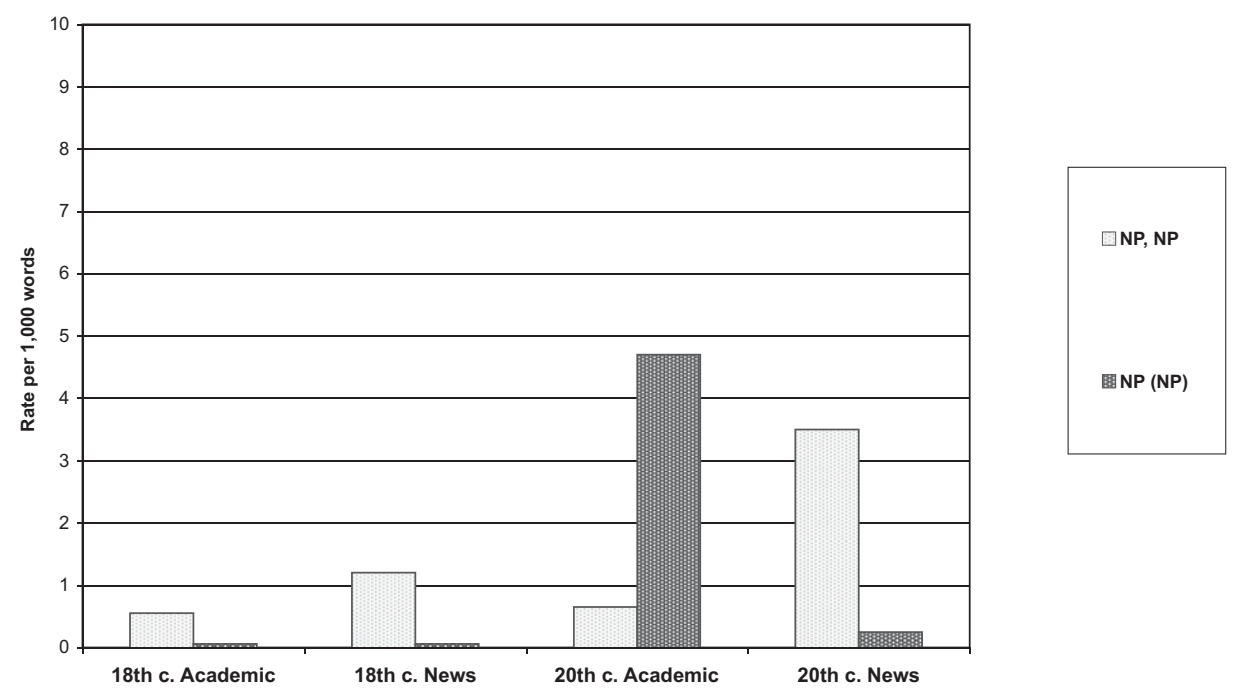

Figure 9. Appositive noun phrases as nominal postmodifiers

(4) In multivariate analyses that adjusted for age and sex, renal involvement (hazard ratio $[H R]=1.9 ; 95 \%$ confidence interval $[C I]: 1.4$ to 2.5$)$, cardiac involvement $(H R=$ 2.8; 95\% CI: 2.1 to 3.8), pulmonary involvement (HR $=1.6 ; 95 \%$ CI: 1.3 to 2.2 ), and anti-topoisomerase I antibodies (HR $=1.3 ; 95 \%$ CI: 1.0 to 1.6$)$ increased mortality risk.

One possible explanation for these historical developments is the unique production circumstances of writing, which permit extensive planning and revision, in contrast to the real-time production circumstances of speech. That is, writers can take as much time as they want to plan exactly what they want to write, and if they write something unintended, they can delete/add/revise/edit the language of the text. Thus, the final written text that an external reader sees might bear little resemblance to the initial words that the author produced, and readers usually have no overt indication of the extent to which the author has revised the original draft. Nearly all written registers offer the opportunity for extensive planning and revising during production, even if the author does not avail him/herself of this opportunity.

Other communicative factors are also influential here, such as the information explosion', the associated need for economy of expression as there is more information to be communicated, and the increasing specialization of the audience. However, it is the production circumstances that seem to be an essential component. For example, Biber (2006) shows that present-day university classroom teaching lacks these characteristics, despite the fact that it conveys informational content to specialist audiences. The primary situational difference between classroom teaching and written academic prose is that classroom teaching is produced in real-time, while the other registers have been 
extensively revised and edited. As a result, classroom teaching employs a clausal style of discourse, while academic writing employs extensive phrasal modifiers.

These contrasting grammatical styles do not represent an absolute or necessary difference between speech and writing. Rather, authors can exploit the written mode to produce texts that are very similar to the typical linguistic styles of speech (as in fiction). However, the converse is not true: that is, speakers are not normally able to revise and edit their speech because they are constrained by real-time production circumstances. As a result, some written registers have evolved to exploit styles of linguistic expression - with extreme lexical diversity and a dense use of complex noun phrase structures - that are not normally feasible in the spoken mode.

The historical developments documented above represent a fundamental shift in the discourse style of academic writing, with grammatical patterns of use that are not attested in any register in earlier historical periods. However, this historical change entails more than just a stylistic shift in the density of nominal/phrasal features. Rather, the individual grammatical features have also undergone important extensions in their uses and functions, accompanying these dramatic increases in frequency. In the sections below, we consider two of these grammatical features in more detail: nouns as nominal premodifiers and prepositional phrases as nominal postmodifiers. In both cases, major new grammatical functions have emerged in informational written discourse over the past two centuries. It is difficult to document the initial emergence of these grammatical structures, which occurred several centuries ago. However, for each of these features, it is possible to document new or extended grammatical functions that have developed in writing over the past two centuries.

3 The development of new grammatical functions in writing

\subsection{Nouns as nominal premodifiers}

The changing patterns of use for nouns as nominal premodifiers, shown in figures 5 and 6 above, reflect more than just an increase in frequency. Rather, there has also been a steady expansion of meaning and function with these structures. Four factors are considered here: (1) the meaning of the premodifying noun itself; (2) the use of nominalizations in noun-noun sequences; (3) the use of multiple premodifying nouns; (4) the logical meaning relationships between the nouns. ${ }^{2}$

\footnotetext{
2 Noun-noun sequences can additionally be analyzed for a number of syntactic distinctions. For example, Huddleston \& Pullum et al. (2002: 448ff) distinguish between NN sequences functioning as "composite nominals' (e.g. lemon sorbet, microfilm reader) versus sequences that represent compounds (e.g. ice-cream). This distinction is related to the status of the premodifying noun as an 'adjunct' (or 'modifier') versus 'complement' (e.g. London newspapers versus television screen; see Huddleston \& Pullum et al. 2002: 449, Rosenbach 2007: 146-7). Rosenbach (2007) further distinguishes between 'classifier' versus 'determiner' functions for premodifying nouns that are complements. While it is possible to cite clear-cut examples for these distinctions, many natural occurrences of $\mathrm{NN}$ sequences are intermediate and difficult to classify. Thus, consideration of such syntactic factors is beyond the scope of the present study.
} 
To investigate these factors in more detail, we undertook a qualitative analysis of noun-noun sequences in medical prose and newspaper articles from the ARCHER Corpus. In the seventeenth and eighteenth centuries, nearly all premodifying nouns can be grouped into three general sematic categories: title nouns, place/location nouns and concrete/tangible nouns:

\section{Title nouns: ${ }^{3}$}

King, Doctor, Duke, Captain, Lord, etc.

Place nouns:

specific places:

Hampton Court, Dumbarton Castle, India Company, Greenwich Park, Boston papers, London gazette

general locations:

country habitations, farm houses, field marshall, frontier garrisons, ground floors, home affairs, town wall

\section{Concrete/TAngible nouns:}

cannon ball, castle hill, chamomile tea, coffee house, copper mill, corn field, foot soldiers, flannel roller, fountain water, goose eggs, gun ship, hen eggs, iron chain/particles/tools, linen handkerchief, milk diet, mineral taste/spring(s)/poisons, sand bank, sea captains, spring water, tea commissioners

By the late 1800s, when the overall frequency of noun-noun sequences began to increase, there was also a marked expansion in the range of meanings expressed by premodifying nouns. Thus, in addition to the categories described above, we find premodifying nouns commonly used to refer to institutions, states or conditions, and other intangibles:

\section{INSTITUTIONS:}

family history, school proposal, state convention, union member

States or conditions (often diseases in medical prose):

cancer cells, croup cases, diphtheria results, health department, maternity hospitals, smallpox eruption

\section{OTHER INTANGIBLES:}

class examinations, currency troubles, credit foncier, heat apoplexy, weather bureau, temperature chart, quarantine restrictions

\footnotetext{
${ }^{3}$ In the sixteenth century, nouns as premodifiers were most commonly titles (such as King, Master, or Doctor; see Raumolin-Brunberg's 1991 analysis of noun phrase structures in Sir Thomas More's writings).
} 
In addition, nominalizations began to be used in noun-noun sequences in the mid nineteenth century, both as the head noun (e.g. school proposal, class examinations, quarantine restrictions) and as the premodifying noun (see also Banks 2008: 133). For the most part, these are nouns referring to processes or activities; they are derived from verbs, either through morphological derivation or through conversion. For example:

\section{NOMINALIZATIONS AS PREMODIFIER, REFERRING TO PROCESSES OR ACTIVITIES:}

Nouns morphologically derived from verbs:

extradition treaty, government officials, inoculation experiments, insurance companies, investigation department, publication house, service reform, taxation prospects

Verb to noun conversion:

awards bureau, murder trials, research fund, trade legislation

This expansion continued throughout the twentieth century, with a much greater range of intangible nouns and nominalized forms (derived from verbs) being used as noun premodifiers; for example:

\section{INTANGIBLE NOUNS:}

age group, casualty department, emergency powers, income tax, monopoly act, news agency, peace conference, press conference, price commission, sector strike, sex differences, television interview, time interval, wage increases, weight loss

Nominalizations REFERRING TO PROCESSES OR ACTIVITIES:

correlation coefficients, labour unions, population base, regression analysis, reprisal raids, study period, terrorism centre, trade agreement, transport unions

In addition, nominalized forms derived from nouns or adjectives also came to be commonly used as noun premodifiers in the twentieth century. These nouns typically refer to abstract attributes or qualities rather than processes. For example:

\section{NOMINALIZATIONS REFERRING TO ABSTRACT ATTRIBUTES OR QUALITIES:}

freedom movement, intelligence agencies, majority group, memorial service, mortality rate, safety officials, security interests

A third type of extension is the use of noun phrases with multiple premodifying nouns, as in justice department official. The only occurrences of this type found in our corpus before 1800 were proper names with multiple titles, as in Minister Count Kinski, Lieutenant Colonel Longueville, Madame Countess d'Etrees. NNN sequences begin to appear in common noun phrases in the late nineteenth and early twentieth centuries, but they are still relatively rare; examples in the ARCHER Corpus include: army reorganization scheme, cancer research associations/fund, Dublin hospital reports, home rule bill, interest charge amounts, river colony politics, trade union leader. 
The dramatic change in use for these structures occurred in the second half of the twentieth century, when NNN sequences become relatively common, and even NNNN sequences are not unusual. For example:

1950-1990 NEWSPAPER PROSE:

Three-noun sequences:

air force machines, aviation security committee, fighter pilot training, health department clinics, house personnel office, justice department intervention, justice department official, justice department spokesman, news agency correspondent/reports, oil tanker drivers, police motorcycle outriders, polio vaccination situation, road haulage association/drivers/industry, settlements tax increases, task force officers, trade boycott campaign, transport labour unions

Four-noun sequences:

emergency cabinet committee meetings, peace treaties enforcement action

1950-1990 MEDICAL PROSE:

Three-noun sequences:

acid phosphatase activity/levels/test/units/values, air flow limitations, artery blood flow, assay dilution factor, blood glucose level, blood pressure clinic, body surface area, chromosome gene product, daytime serum concentrations, granulocyte adhesion functions, granulocyte surface membrane, haemoglobin digestion method, hazards regression analyses, hepatitis surface antigen, hill committee report, hill report recommendations, hospital record departments, infarction blood pressure, insulin infusion tests, life insurance tables, (early) morning urine specimens, mouse ascites fluid, nitrogen excretion supply, peak plasma concentrations/levels, pearson correlation coefficients, plasma concentration curve, plasma glucose levels/profile/value, rabbit immunoglobulin fractions, (high) resolution image intensifier, sinus node dysfunction

Four-noun sequences:

life table survival curves, peak mean plasma concentration, mean plasma glucose value, plasma concentration time curve

Finally, there has been historical extension in the meaning relationships that hold between a premodifying noun and the head noun. The title nouns and place nouns found as premodifiers in the seventeenth and eighteenth centuries are straightforward in this regard. For example, Captain Smith is a person named Smith who is a captain; Greenwich Park is a park located in Greenwich; frontier garrisons are garrisons located at the frontier.

The other classes of premodifying nouns, though, do not consistently express a single meaning relationship to the head noun. This is true even for the concrete/tangible nouns found as premodifiers in the eighteenth century. For example: 
NN SEQUENCE iron chain/tools, linen handkerchief milk diet, chamomile tea, flannel roller, mineral spring(s)/poisons

hen eggs, goose eggs, fountain water, spring water

coffee house, copper mill, corn, field, gun ship, sand bank

sea captains, tea commissioners

cannon ball, farm house, town wall
Paraphrase

an N2 that is composed of N1

an $\mathrm{N} 2$ that comes from $\mathrm{N} 1$

an N2 where one can find N1

an $\mathrm{N} 2$ specializing in $\mathrm{N} 1$

an N2 used for/with an N1

The set of possible meaning relationships expands greatly in the late nineteenth century and throughout the twentieth century, associated with the wider range of premodifying nouns. Following is a sample of the additional meaning relationships commonly expressed by NN sequences in the late twentieth century:

NN SEQUENCE

government official, union member

state convention, union assets

family history, psychology lecture, sports magazine, algebra textbook

awards bureau,

investigation department,

price commission,

safety officials

casualty department,

intelligence agencies,

news agency,

terrorism centre

extradition treaty,

monopoly act,

research fund
Paraphrase

a person (N2) belonging to the institution identifed by $\mathrm{N} 1$

an inanimate entity (N2) associated with the institution identifed by $\mathrm{N} 1$

a text (N2) about the topic identified in N1

a person or institution (N2) that regulates or administers N1

an institution (N2) that tries to obtain information about $\mathrm{N} 1$

an inanimate entity (N2) that regulates or administers N1

The grammatical use of nominalizations as head nouns in these complex noun phrases (introduced in the nineteenth century; see above) results in additional meaning relationships. In many cases, the premodifying noun is the semantic patient or theme of the process described by the nominalized head noun. Many of these head nouns are derived from intransitive verbs; in those cases, the premodifying noun corresponds to the logical subject (e.g. compare the noun phrase wage increases to the clause wages increased). Other head nouns are derived from transitive verbs; in those cases, the premodifying noun corresponds to the logical direct object (e.g. compare the noun 
phrase waste disposal to the clause someone disposed of the waste). In other cases, the premodifying noun identifies the purpose or topical domain of the process described by the nominalized head noun (e.g. peace conference). For example:

wage increases, eye movement, child development, justice department intervention weight loss, waste disposal, income tax, taxi driver, trade legislation

trade agreement, reprisal raids, freedom movement, peace conference
$\mathrm{N} 1$ is a patient or theme affected by the process described by N2; syntactically, $\mathrm{N} 1$ is the logical subject of N2

$\mathrm{N} 1$ is a patient or theme affected by the process described by $\mathrm{N} 2$; syntactically, $\mathrm{N} 1$ is the logical direct object of N2

$\mathrm{N} 1$ identifies the purpose or topical domain of the process described by N2

In some cases, both nouns are nominalized processes. For example, a regression analysis refers to 'someone analyzing the way in which variable $\mathrm{X}$ regresses with variable $Y^{\prime}$.

In addition, there are many more specific meanings for particular NN sequences. For example:

$\mathrm{NN}$ SEQUENCE
age group
correlation coefficients
emergency powers
inoculation experiments
retail outlet
pressure hose
pressure ratio
$\mathrm{NNN}$ SEQUENCE
oil tanker drivers
trade boycott campaign
$\mathrm{NNNN}$ SEQUENCE
emergency cabinet committee
meetings
peace treaties enforcement action
MeANing Relationship a group consisting of people with a particular age coefficents that report correlations powers that can be used in an emergency experiments that test the effectiveness of inoculation an outlet that sells retail merchandise a hose able to withstand pressure a ratio measuring pressure

MeANing Relationship people who drive tankers that contain oil a campaign to encourage people to boycott trade

MeAning Relationship meetings of a committee associated with a cabinet, called in an emergency activities carried out to enforce treaties intended to result in peace

In sum, there is much more involved in this historical development than simply a large increase in frequency for nouns as premodifiers. In particular, the present section has shown that there has been a major expansion in the types of nouns that can occur as nominal premodifiers, as well as a major expansion in the range of meaning relationships underlying noun-noun sequences. In addition, the use of a single noun as premodifier has been extended in the last century to permit two and three premodifying nouns, and this extension seems to be continuing up to the present time. The following section documents similar extensions in grammatical and semantic functions for the use of prepositional phrases as nominal modifiers. 


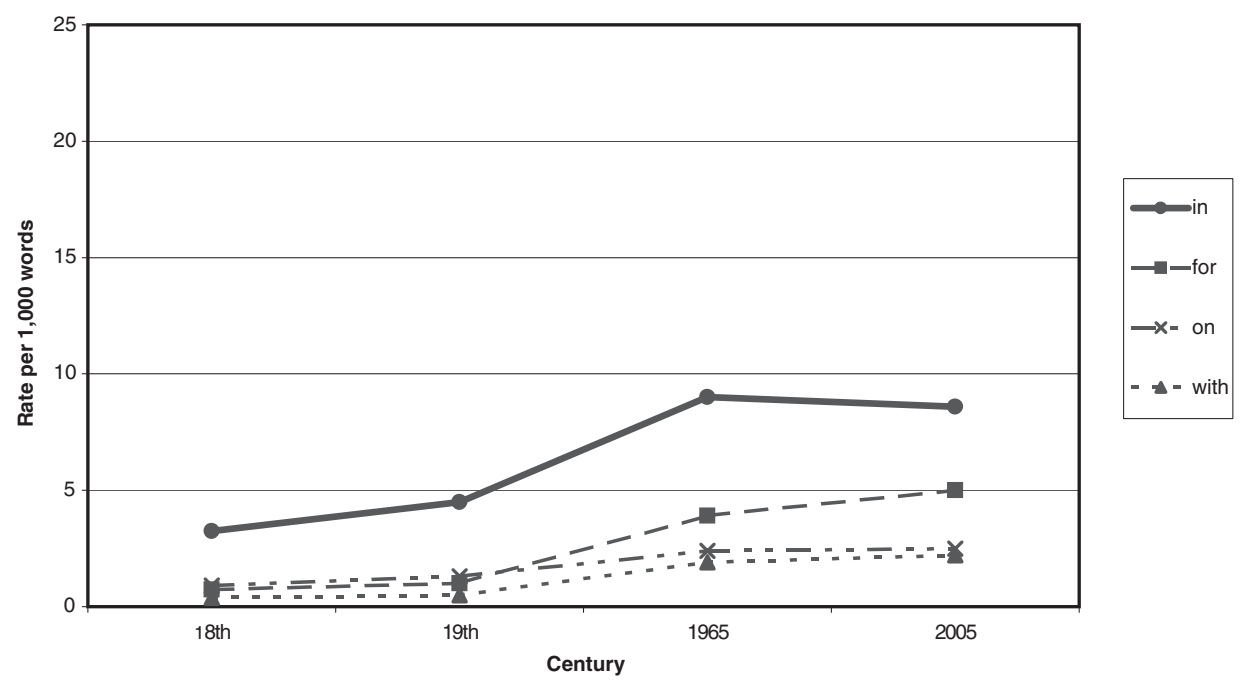

Figure 10. Growth in the use of specific 'other' prepositions in PPs as nominal postmodifiers, in medical prose (and twentieth-century science)

\subsection{Prepositional phrases as nominal postmodifiers}

Figure 8 above shows that of-genitives were already common in the seventeenth century, and that they have continued to be frequent in informational writing up to the present time.$^{4}$ In contrast, other prepositonal phrases (PPs) as noun modifiers have shown a strong increase in use over the last century.

Figure 10 provides more details, showing the historical development of each individual preposition as postnominal modifier. The preposition in takes the lead here, being in use already in the eighteenth century and then showing a strong increase in use during the nineteenth and twentieth centuries. In contrast, PPs with for, on and with were quite rare in the eighteenth century and showed only a small increase in the nineteenth century, followed by a strong increase in the twentieth century. As figure 11 shows, this historical change has not occurred in conversation, where the use of these prepositons as noun modifiers is still extremely rare.

Similar to the historical changes described above for noun-noun sequences, the increased use of PP noun modifiers has been accompanied by a large expansion in function and meaning. One grammatical development is the increasing ability of these prepositions to occur as a nominal postmodifier with an ing-clause as complement, as in:

(5) (a) the value of full doses in treating cancer

(b) the first step in seeking quicker treatment

(c) difficulty in separating the sarcoplasmic proteins from the myofibrils

${ }^{4}$ Szmrecsanyi \& Hinrichs (2008) document further historical change in the use of of-genitives compared to 's-genitives. 


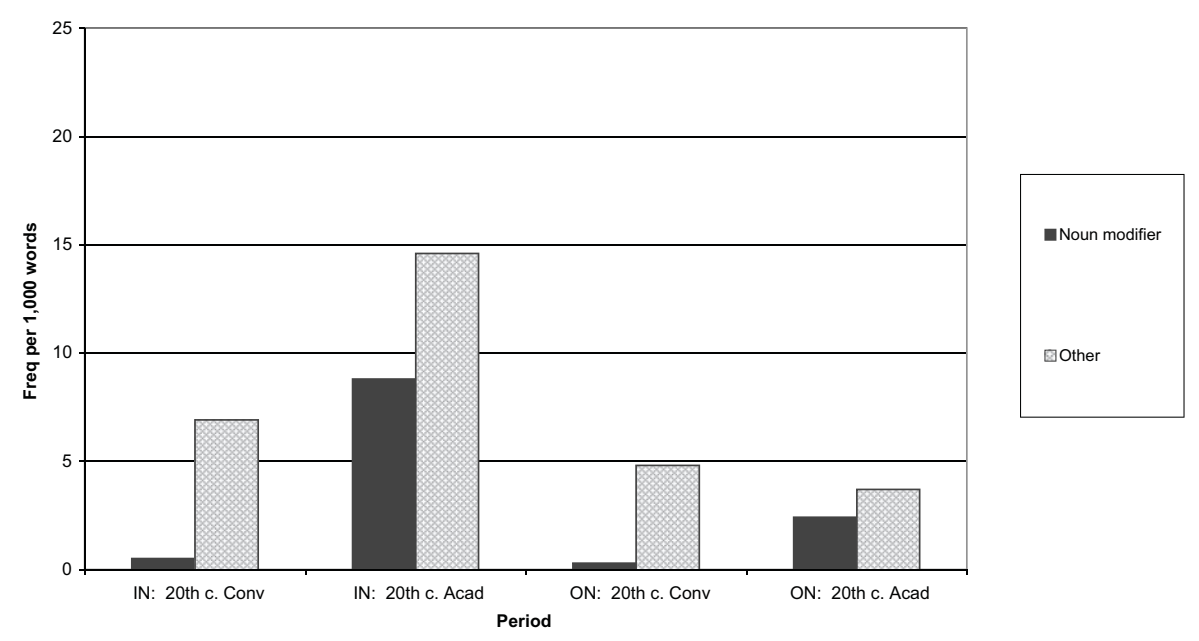

Figure 11. IN and ON as noun-modifier versus 'Other' syntactic functions: conversation vs academic writing

(d) errors in rounding the total score

(f) motives for committing a violent crime

(g) plans for creating a UFO

Early occurrences of this structural pattern are attested from Middle English and Early Modern English; examples (6)-(9) are from seventeenth-century medical prose (see Biber et al. 2011):

(6) the vertues and worth of this Medicine in helping and curing many diseases

(7) pains in making water

(8) the difficulty in searching out the causes of them

(9) the truth of the marchaunt in transporting the same

However, as shown in figure 12, the structure was still rare by the beginning of the nineteenth century, but it has increased in use over the course of the twentieth century. Prepositional phrases with in and for take the lead here, while phrases with on + ing-clause are expanding in use more slowly.

It is possible to track the historical progression of this structure to an increasing number of different controlling nouns. In many cases, these structures have an earlier historical counterpart with a prepositional verb + ing-clause. Witness in this respect the following examples from the $O E D$, showing the first attestation of a verb or noun with the preposition in followed by an ing-clause:

(10) (a) 1572 such as men use in searching ore

(b) 1620 it hath special use in illustrating [something]

(11) (a) 1647 assist in procuring [something]

(b) 1742 assistance in apprehending [something] 


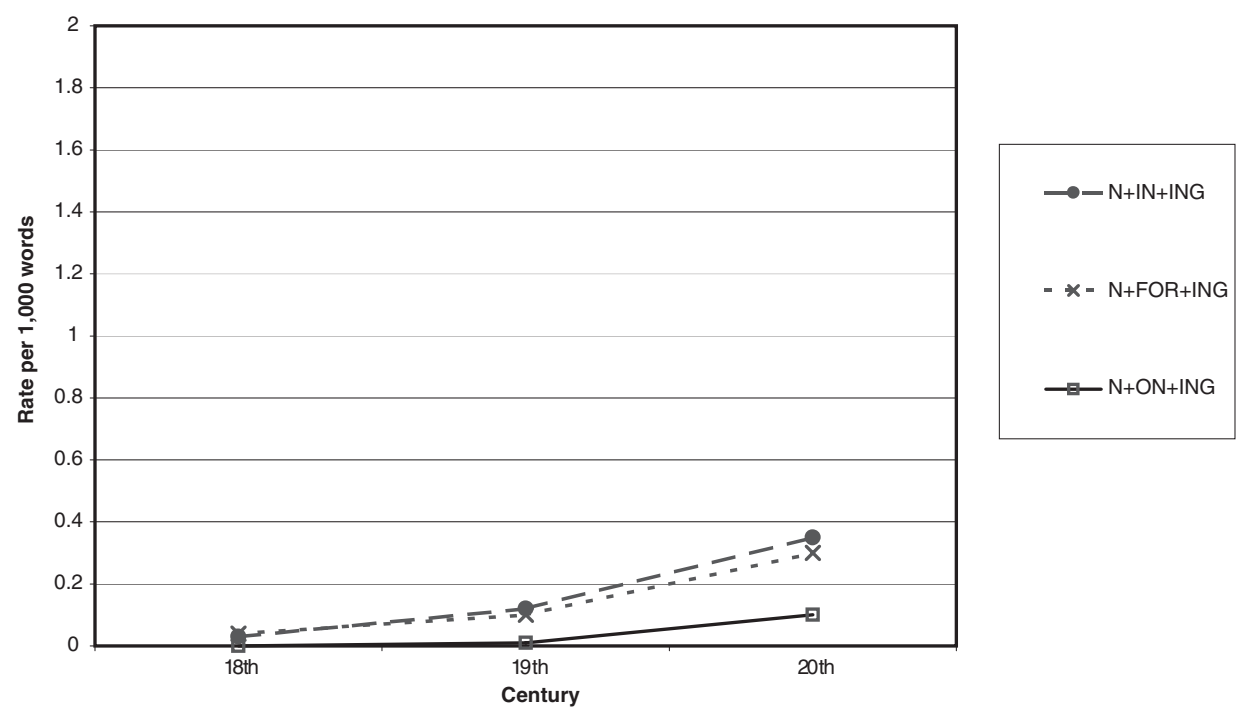

Figure 12. Noun + Preposition + ING-clause in academic prose

(12) (a) 1730 succeed in forcing [something]

(b) 1820 success in capturing [something]

(13) (a) 1606 persist in doing wrong

(b) 1874 persistency in seeking a pacific settlement

(14) (a) 1940 [they] specialize in hunting big game

(b) 1970 specialisations in printing [something]

In addition to extensions in grammatical function, it is also possible to track historical extensions in the range of meaning relations that can be signaled by these PP noun modifiers. For example, in present-day academic prose, the prepositions in and on can express both concrete locative meanings (blood flow in skin and in skeletal muscle; many places on the slopes below) and abstract meanings (evolution in Roosevelt's imperialist thought; the influence of evolutionary ideas on his public policies). However, the use of these prepositions to express abstract meanings is a relatively recent development restricted primarily to writing. Thus, in conversation, over 90 percent of these PPs as noun modifiers express concrete/locative meanings, as in (15a-f):

(15) (a) glasses in the envelope

(b) a vault in his house

(c) those kids in California

(d) stuff on the dash

(e) that thing on the roof

(f) did you read that dedication on the first page

This is similar to the typical uses of these prepositions in the sixteenth-seventeenth centuries, where they normally expressed concrete/locative meanings even in academic written prose (see Biber et al. 2011). For example: 


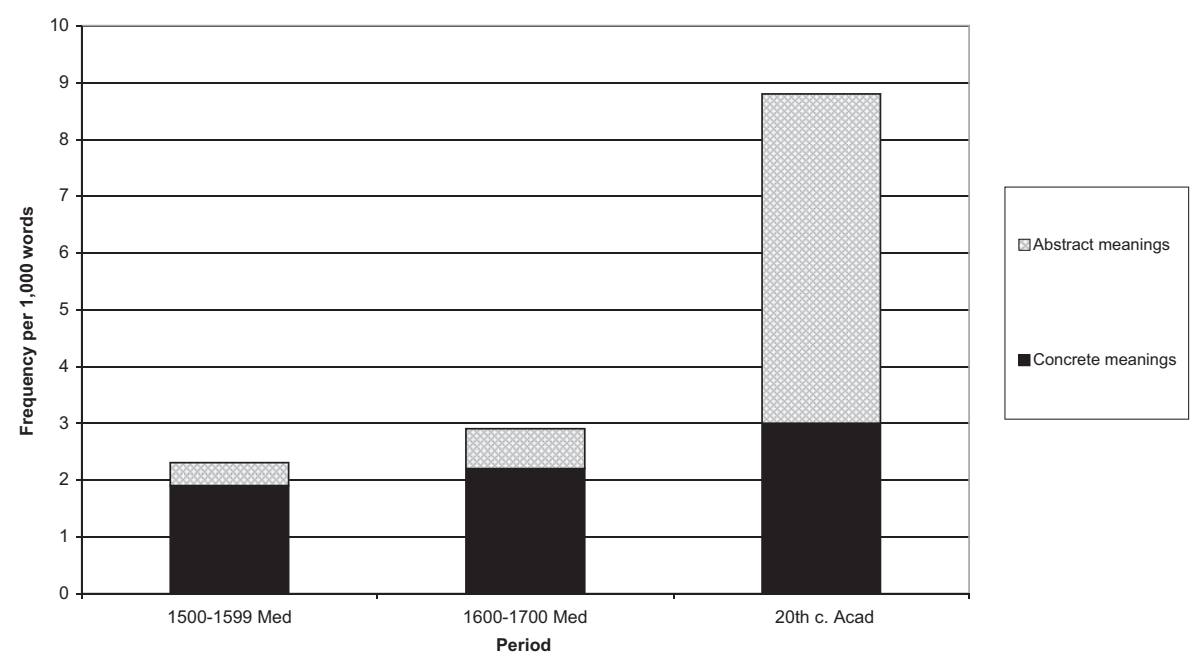

Figure 13. IN as noun-modifier: concrete versus abstract meanings

Meanings expressed by noun-modifying PPs with in; seventeenth-century medical prose:

$\mathrm{N}+\mathrm{PP}$ SEQUENCE

a wynde in the heed,

ache in the backye,

pain in his knee

the oil in the thermometer,

kernels in your meat,

quantity of opium in it

our apothecaries in England,

John Bissite in St Peters Parish

the foregoing chapters in the

first part, his judgement and candor

in his writings
MeANing

location inside a body part

location inside an object or substance

geographic location

textual location

Meanings expressed by noun-modifying PPs with on; seventeenth-century medical prose:

$\mathrm{N}+\mathrm{PP}$ SEQUENCE

a postume on the longes,

blisters and hackes on the lips,

two on each side
MeAning

location on the surface of an object

As figures 13 and 14 show, these concrete meanings were typical for in/on nounmodifying PPs in the sixteenth and seventeenth centuries. Abstract meanings with on were especially rare, restricted to an identification of 'topic', as in (16) to (19):

(16) a poem on the virtue of a laurel leaf 


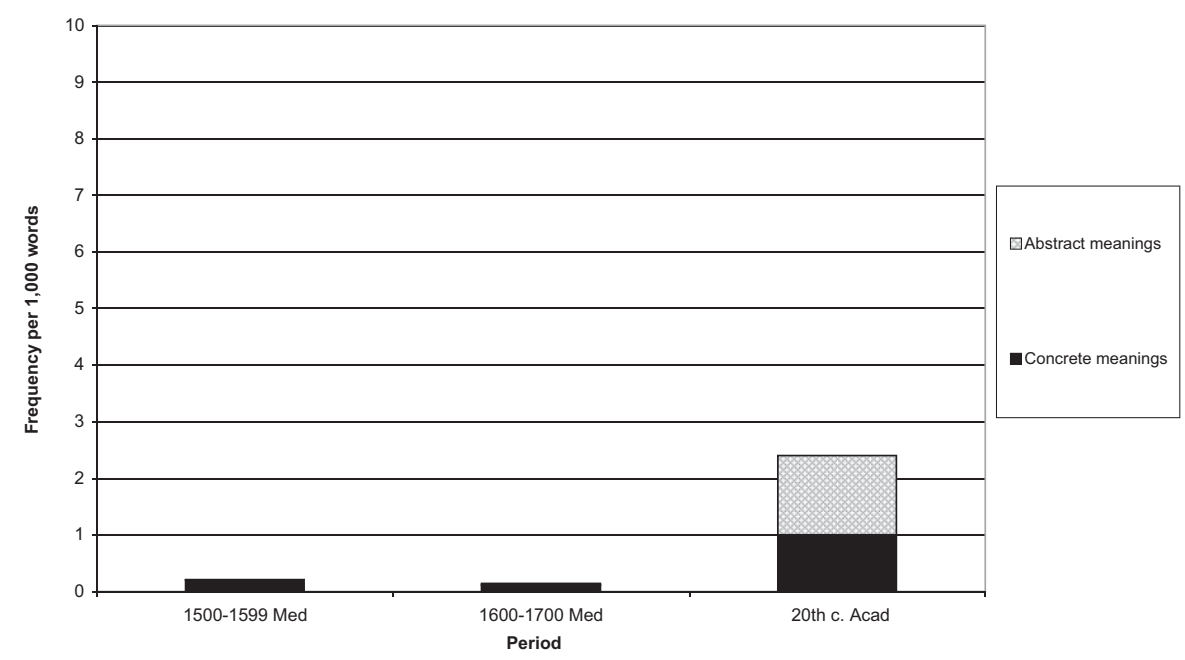

Figure 14. ON as noun-modifier: concrete versus abstract meanings

(17) some remarks on the late debate about $\mathrm{X}$

(18) occasional notes on dr. George Thompsons

(19) a learned author on this subject

PPs with in had a similar abstract use in the seventeenth century, identifying a general research domain, as shown in (20) to (23):

(20) my studie in ciuile and humane learnynge

(21) that Axiome in philosophie

(22) his learning in all sciences

(23) our work in the Astrological or chymical way of physic

Over the three intervening centuries, these prepositions have developed a range of abstract uses, so that in present-day written academic prose, around 60 percent of all occurrences express abstract rather than concrete meanings.

Most interestingly for our purposes here, each of these prepositions has developed a specialized abstract meaning that marks the modifying noun as the semantic 'patient' of the process described by the head noun, as (24) and (25) illustrate:

(24) an increase in efficiency

(cf. something increased efficiency, or efficiency increased)

(25) influence on dropout rates

(cf. something influenced dropout rates)

For PPs with in, these head nouns usually correspond to an intransitive verb, as in (26)-(28):

Subject NP ('patient') + Intransitive V > Head noun (identifying a process) $+i n+$ NP ('patient') 
(26) the chief reason for Britain's decline in exports

(cf. Britain's exports declined)

(27) a rapid increase in the size of the egg

(cf. the size of the egg increased)

(28) variation in frequency

(cf. the frequency varied)

For PPs with on, these head nouns correspond to transitive verbs, as in (29)-(31) and (32)-(34):

Transitive V + Object NP ('patient') $>$ Head noun (identifying a process) + on $+\mathrm{NP}$ ('patient')

(29) a significant influence on the tragic developments that followed

(cf. something influenced the tragic developments)

(30) two factors have the greatest impact on college grades

(cf. two factors impact college grades)

(31) a greater emphasis on intellectual behaviours

(cf. someone emphasises intellectual behaviours)

Transitive Prepositional V + on + Object NP ('patient') $>$ Head noun (identifying a process $)+o n+\mathrm{NP}$ ('patient')

(32) a biological dependence on physical conditions

(cf. it depends on physical conditions)

(33) his reliance on the evolutionary thesis

(cf. he relied on the evolutionary thesis)

(34) a focus on measures of student outcomes

(cf. someone focused on measures of student outcomes)

In present-day informational writing, there are numerous head nouns that can take these patterns. Seven head nouns are especially frequent with in plus an NP ('patient'): change, decrease, difference, fall, increase, rise and variation. (Other head nouns that occur with this pattern include: advances, breakdown, decline, development, evolution, growth, improvement, reduction and shift.) Similarly, there are numerous head nouns that take on plus an NP ('patient'): effect and emphasis are especially frequent with this pattern, but other nouns include attack, constraint, debate, decision, discussion, impact, influence, limit, limitation, restriction. There are fewer prepositional verbs that have been nominalized to occur as head nouns in this pattern, such as bearing on, dependence on, focus on, insistence on and reliance on.

These grammatical uses have been introduced gradually over the past four centuries in informational written texts. The pattern with the preposition in historically precedes the pattern with on, corresponding to the overall development of in and on PPs as nominal modifiers, shown in figure 10 above. In PPs with this meaning seem to have first occurred in the sixteenth century with the head nouns difference and change, and this pattern then gradually spread to other process nouns over the following four centuries. Thus, (35)-(43) are the first attested examples for selected process nouns + in + NP ('patient') from the $O E D$ : 
(35) 1530 no difference in sounde

(36) 1585 to attempt alteration and change in the church of God

(37) 1627 one inch of decrease in the growth of men

(38) 1760 improvement in the art of ... defending strong places

(39) 1804 a fall in the price of the article

(40) 1806 great variation in its composition

(41) 1817 a small rise in the annual payment

(42) 1823 a sudden increase in the circulating medium

(43) 1869 quick growth in intellectual and moral force

The prepositional verb depend on seems to have participated in this development at a relatively early stage (44), but nominalized equivalents of other prepositional verbs with on, such as (45)-(47), appear considerably later (first attested examples from the $O E D)$ :

(44) 1605 dependance on the Latin

(45) 1754 reliance on the promises of God

(46) 1798 insistance on tradition

(47) 1908 a focus on passing pedestrians

As (48) to (50) show, other process nouns that take on + NP ('patient') lagged behind these other structures by about a century:

(48) 1696 Absence, Madam, has had the same effect on my Passion

(49) 1869 their impact on the atoms

(50) 1899 their emphasis on the partial nature of all physiological analysis.

The development of in/on as noun-modifying PPs could be described in much more detail, and complemented by descriptions of the other prepositions occurring in similar patterns. The descriptions here, however, have documented linguistic innovation and change at multiple levels: in the overall extent to which a structure is used; in the particular structural variants that occur; and in the meaning relationships expressed by the structure. The available evidence indicates that these innovations were all initiated in writing and have subsequently developed in informational written discourse, with little transfer to spoken conversational discourse at all.

\section{Summary and conclusion}

We initially surveyed the historical patterns of use for five phrasal devices used for noun phrase compression or modification (nominalizations, attributive adjectives, appositive noun phrases, nouns as nominal premodifiers and prepositional phrases as nominal postmodifiers), and then considered the last two of these in more detail. It is not possible to prove that these constructions were first used in writing rather than in speech. What is clear, though, is that these have become 'written' grammatical characteristics over the past two centuries, while they have remained rare in spoken conversational discourse. 
This historical development is not merely a change in discourse style realized as an increase in the frequency of use for these features. Rather, the grammatical features themselves have undergone major extensions in their lexical associations, grammatical variants and functions, and meanings. These extensions have all emerged in informational writing, associated with the communicative demands and production circumstances of that register.

Interestingly, these developments conform to the general claim that language changes all occur 'in the same direction, essentially towards reduction and tighter integration of form' (Croft 2000: 62). Hopper \& Traugott (2003: 71-3) similarly describe the drive towards economy of expression in historical change. The focus in those studies is on reductions that lead to simplification of the speech signal (e.g. be going to $\rightarrow$ be gonna, you know $\rightarrow$ yaknow, you all $\rightarrow$ yall). However, similar forces seem to be in play with the shift from clausal styles of expression to phrasal styles, with information compressed into noun phrases.

In summary, these findings strongly support the general claim that grammar emerges in natural communicative situations, but they argue against the position that those situations are restricted to spoken interaction. Rather, it seems likely that new grammatical uses and functions can emerge in any register - spoken or written associated with the distinctive situational and communicative characteristics of that register.

Authors' address:

Department of English

College of Arts and Letters

Northern Arizona State University

Flagstaff, Arizona 86011

USA

Douglas.Biber@nau.edu

Bethany.Gray@nau.edu

\section{Corpora}

Corpus of 20th century research articles, compiled by Bethany Gray (Northern Arizona University).

Corpus of historical fiction, compiled by Bethany Gray (Northern Arizona University).

A representative corpus of historical English registers (ARCHER). 1992. ARCHER1 compiled by Douglas Biber (Northern Arizona University) and Edward Finegan (University of Southern California). www.llc.manchester.ac.uk/research/projects/archer/.

Corpus of English texts on astronomy (CETA), compiled by the Research Group for Multidimensional Corpus-Based Studies in English (MUStE) at the University of A Coruña, Spain. www.udc.es/grupos/muste/research/index.html.

Longman spoken and written English corpus, see Biber et al. 1999: 24-35.

Oxford English dictionary (OED). 2009. Oxford University Press. www.oed.com. Accessed as a searchable corpus at http://corpus.byu.edu. 


\section{References}

Banks, David. 2008. The development of scientific writing: Linguistic features and historical context. London: Equinox.

Barlow, Michael \& Suzanne Kemmer (eds.). 2000. Usage-based models of language. Stanford, CA: CSLI Publications.

Biber, Douglas. 1988. Variation across speech and writing. Cambridge: Cambridge University Press.

Biber, Douglas. 2006. University language: A corpus-based study of spoken and written registers. Amsterdam: John Benjamins.

Biber, Douglas. 2009. Are there linguistic consequences of literacy? Comparing the potentials of language use in speech and writing. In David R. Olson \& Nancy Torrance (eds.), Cambridge handbook of literacy, 75-91. Cambridge: Cambridge University Press.

Biber, Douglas \& Victoria Clark. 2002. Historical shifts in modification patterns with complex noun phrase structures: How long can you go without a verb? In Teresa Fanego, María José López-Couso \& Javier Pérez-Guerra (eds.), English historical syntax and morphology, 43-66. Amsterdam: John Benjamins.

Biber, Douglas \& Susan Conrad. 2009. Register, genre, and style. Cambridge: Cambridge University Press.

Biber, Douglas \& Edward Finegan. 1997. Diachronic relations among speech-based and written registers in English. In Terttu Nevalainen \& Leena Kahlas-Tarkka (eds.), To explain the present: Studies in changing English in honor of Matti Rissanen, 253-76. Helsinki: Société Néophilologique. [reprinted in Conrad and Biber 2001, 66-83]

Biber, Douglas \& Bethany Gray. 2010. Challenging stereotypes about academic writing: Complexity, elaboration, explicitness. Journal of English for Academic Purposes 9, 2 20.

Biber, Douglas, Bethany Gray, Alpo Honkapohja \& Päivi Pahta. 2011. Prepositional modifiers in early English medical prose: A study on their historical development in noun phrases. In Päivi Pahta \& Andreas H. Jucker (eds.), Communicating early English manuscripts, 197-211. Cambridge: Cambridge University Press.

Biber, Douglas, Stig Johansson, Geoffrey Leech, Susan Conrad \& Edward Finegan. 1999. Longman grammar of spoken and written English. London: Longman.

Bybee, Joan \& Paul Hopper (eds.). 2001. Frequency and the emergence of linguistic structure. Amsterdam: John Benjamins.

Croft, William. 2000. Explaining language change: An evolutionary approach. London: Longman.

Fox, Barbara. 2007. Principles shaping grammatical practices. Discourse Studies 9, 299-318.

Halliday, M. A. K. 1979. Differences between spoken and written language: Some implications for language teaching. In Glenda Page et al. (eds.), Communication through reading: Proceedings of the 4th Australian reading conference, 37-52. Adelaide: Australian Reading Association.

Halliday, M. A. K. \& J. R. Martin. 1993/1996. Writing science: Literacy and discursive power. London: Falmer Press.

Hopper, Paul J. \& Elizabeth C. Traugott. 2003. Grammaticalization, 2nd edn. Cambridge: Cambridge University Press.

Huddleston, Rodney \& Geoffrey K. Pullum et al. 2002. The Cambridge grammar of the English language. Cambridge: Cambridge University Press.

Kemmer, Suzanne \& Michael Barlow. 2000. Introduction: A usage-based conception of language. In Barlow \& Kemmer (eds.), vii-xxviii.

Krug, Manfred G. 2000. Emerging English modals: A corpus-based study of grammaticalization. Berlin: Mouton de Gruyter. 
Langacker, Ronald W. 1987. Foundations of Cognitive Grammer. Stanford University Press.

Langacker, Ronald W. 2000. A dynamic usage-based model. In Barlow \& Kemmer (eds.), $1-64$.

Leech, Geoffrey, Marianne Hundt, Christian Mair \& Nicholas Smith. 2009. Change in contemporary English: A grammatical study. Cambridge: Cambridge University Press.

Mair, Christian. 2006. Twentieth-century English: History, variation and standardization. Cambridge: Cambridge University Press.

Meyer, Charles. 1992. Apposition in contemporary English. Cambridge: Cambridge University Press.

Nevalinna, Saara \& Päivi Pahta. 1997. Middle English nonrestrictive expository apposition with an explicit marker. In Jacek Fisiak (ed.), Studies in Middle English linguistics, 373-402. Berlin: Mouton de Gruyter.

Ochs, Elinor, Emanuel A. Schegloff \& Sandra A. Thompson (eds.). 1996. Interaction and grammar. Cambridge: Cambridge University Press.

Pahta, Päivi \& Saara Nevalinna. 1997. Re-phrasing in Early English: The use of expository apposition with an explicit marker from 1350 to 1710. In Matti Rissanen, Merja Kytö \& Kirsi Heikkonen (eds.), English in transition: Corpus-based studies in linguistic variation and genre styles, 121-83. Berlin: Mouton de Gruyter.

Raumolin-Brunberg, Helena. 1991. The noun phrase in early sixteenth-century English: A study based on Sir Thomas More's writings. Helsinki: Société Néophilologique.

Rosenbach, Anette. 2007. Emerging variation: Determiner genitives and noun modifiers in English. English Language and Linguistics 11, 143-89.

Szmrecsanyi, Benedikt, \& Lars Hinrichs. 2008. Probabilistic determinants of genitive variation in spoken and written English: A multivariate comparison across time, space, and genres. In Terttu Nevalainen, Irma Taavitsainen, Päivi Pahta \& Minna Korhonen (eds.), The dynamics of linguistic variation: Corpus evidence on English past and present, 291-309. Amsterdam: John Benjamins.

Tagliamonte, Sali. 2004. Have to, gotta, must: Grammaticalisation, variation and specialization in English deontic modality. In Hans Lindquist \& Christian Mair (eds.), Corpus approaches to grammaticalization in English, 33-55. Amsterdam: John Benjamins.

Traugott, Elizabeth C. 2003. From subjectification to intersubjectification. In Raymond Hickey (ed.), Motives for language change, 124-39. Cambridge: Cambridge University Press. 